\title{
UNESCO's Archival Collections: A Rich Source for Telling the Gripping Story of the Fight against Illiteracy in Southern Italy
}

It all began with the exploration of UNESCO's audio-visual collections after their recent transfer to the UNESCO Archives. Most of these collections had barely been indexed in the course of their seventy-year history. We therefore embarked on a literal exploration of the collections with a certain degree of urgency, due to the need to select the materials to be digitized as part of a two-year project scheduled to start soon. Going through the depots felt a little like wandering in Borges's Library of Babel. In the photo depots, the only way to get a grip on how the collection was organized was quite simply to open the many drawers of the many old filing cabinets and have a look at what was inside. It was by opening one of these drawers that we made an astonishing find: a forgotten album of 38 contact sheets and accompanying texts by one of the twentieth century's greatest photographers, David "Chim" Seymour - a report made in 1950 on the fight against illiteracy in Italy's southern region of Calabria. Some of the photos in the album of contact sheets had been selected to illustrate an article in the March 1952 issue of the UNESCO Courier, with text by another 'celebrity,' the writer Carlo Levi, who had gained worldwide fame with his novel Christ Stopped at Eboli (1945).

Having shared the discovery with two specialists in the field of history of photography, Karin Priem and Carole Naggar, we immediately came to the conclusion that we needed to share it also with the wider public. A first step was to digitize the album as part of UNESCO Archives' digitization project and then make it available on the project's platform. However, we also agreed right from the start that the album and the Chim-Levi reportage additionally deserved to be the subject of a book-length publication featuring contextualizing essays. This is how this book came about.

In his essay, Juri Meda argues that a particular public image of rural schools always the poorest and most disadvantaged schools - was frequently disseminated and used by the ruling classes and/or political parties to document the state of mod-

\footnotetext{
I would like to thank Carole Naggar and Karin Priem for the great adventure undertaken together of publishing this book; it has been a great privilege and pleasure to work with them. I am also very grateful to my colleagues at UNESCO Archives \& Library - in particular to Adama Pam, Eng Sengsavang, Coryn Lang, and Adam Cowling - and at UNESCO Publications - especially to Cristina Puerta, Ian Denison, Eric Frogé and Aurélie Torre. Finally, my warmest thanks go to David Atchoarena, Jens Boel, Anthony Krause, and Anne Muller for their advice and feedback. The ideas and opinions expressed in this chapter are those of the author and do not necessarily represent the view of UNESCO.
} 
ernity and/or backwardness of the national school system, depending on their propaganda needs. Taking as his starting point the photo essays by a number of Italian photojournalists (including Tino Petrelli, Federico Patellani, and Ando Gilardi) in the late 1940s and early 1950s, Juri Meda analyzes how the public image of these particular schools was manipulated through the circulation of such photographs in daily newspapers and magazines of different political orientations (such as Epoca, Il Lavoro, etc.).

Carole Naggar focuses her text on the collaboration between Carlo Levi and David "Chim" Seymour, providing an analysis of their relationship and telling the story of how they found a common ground in the exploration of Southern Italy. The two met in 1948 when Chim was covering the Italian elections, and Chim, the son of a Jewish-Polish publisher and an avid reader, was influenced and impressed by Carlo Levi's book Christ Stopped at Eboli and his New York Times articles on the "question of the South," as it was then called. So when the recently founded UNESCO decided to send the Magnum photographer on a mission to cover illiteracy in Southern Italy in 1950, it was a logical choice for him to follow in Levi's tracks and to ask him if Magnum Photos could use one of his articles on illiteracy for distribution together with his photographs. ${ }^{1}$

Finally, Karin Priem, drawing on studies in the philosophy of technology, specifically sheds light on the hidden or even erased technological and material aspects of interpretation and meaning-making. Her essay looks at Seymour's album as a visual object and at the material traces it provides. Applying this perspective to photographic albums makes it possible to analyze photographs as entangled networks of meaning-making that presented, translated, and wove together the world in specific ways. Priem suggests that the album functioned as an editing tool for media campaigns and as a means of communication between the photographer, his editors, and public audiences. Seymour visually captured people's lives and environments, stressed their historical importance by compiling the album, and thus created appealing narratives on the fight against illiteracy in Southern Italy.

In this essay, I would like to set the Chim-Levi reportage in the context of UNESCO's activities in the fight against illiteracy in postwar Southern Italy. ${ }^{2}$ These activities were mostly carried out in cooperation with the main Italian organization operating in the field at the time: the Unione Nazionale per la Lotta contro l'Analfa-

1 Letter from David Seymour to Carlo Levi, 26 December 1951, p. 160 in this volume.

2 For UNESCO's activities in what was called, at the time, "fundamental education," see Jens Boel, "UNESCO's Fundamental Education Program, 1946-1958: Vision, Actions and Impact," in A History of UNESCO: Global Actions and Impact, ed. Poul Duedahl (Basingstoke: Palgrave Macmillan, 2016), 153-67; Maren Elfert, “The Utopia of Lifelong Learning: An Intellectual History of UNESCO's Humanistic Approach to Education, 1945-2015" (PhD diss., University of British Columbia, 2016); Joseph Watras, “UNESCO's Programme of Fundamental Education, 1946-1959," History of Education 39, no. 2 (2010): 219-37. 
betismo (UNLA, National League for the Struggle against Illiteracy). I will take a look at the rich dossier in the UNESCO archives on the relationship between UNESCO and UNLA. By taking this dossier as an example, I hope to show how interesting the study of the primary sources in UNESCO's archival collections can be, and thus to encourage further research.

UNLA was one of the most important private institutions founded in postwar Italy to join in the Italian government's efforts to tackle the serious problem of illiteracy in the South. Starting in 1948, UNLA helped establish numerous schools that offered basic literacy classes for both children and adults. However, UNLA's most original initiative was the creation of the so-called "People's Cultural Centers": under the guidance of a UNLA teacher, adults who had already benefited from the basic literacy classes could pursue their educational efforts by being encouraged to ask questions (quesiti) pertaining to their practical lives but also to more theoretical issues. The UNLA teacher would try to answer them with the support of the literate and professional members of the community (the doctor, the pharmacist, the veterinarian, the parish priest, etc.).

The first exchanges between UNESCO and UNLA date back to 1949. One of the people who feature early on in these exchanges is Paul Lengrand. He was, at the time, an Expert in the UNESCO Education Department, working in the Division of Fundamental and Adult Education. On April 5-9, 1951, UNLA held a conference on adult education in Rome, wrapping up a study and training course for the young head teachers of the various People's Cultural Centers. When UNLA invited UNESCO to send a representative to this conference, UNESCO sent Lengrand.

As it emerged from his report, Lengrand came back from the conference particularly impressed by the presentations of the teachers of the People's Cultural Centers and the subsequent discussions. He wrote:

Most of them are young men (25 to 35 years old) whose skill seems to go hand in hand with zeal and enthusiasm. They are aware of the importance of the task they have undertaken and appear to be on the right track in terms of the goals of their action and the means they use. In private conversations I had with some of them, I was struck by the human quality and the singularly moving enthusiasm of these young educators. ${ }^{3}$

He believed that the good work UNLA was doing should receive UNESCO's support and advised the UNLA Committee to address two main requests to UNESCO: first, to

\footnotetext{
3 "Pour la plupart, il s'agit de jeunes hommes (de 25 à 35 ans) dont la compétence semble aller de pair avec le zèle et l'enthousiasme. Ils ont conscience de l'importance de la tâche qu'ils ont entreprise et paraissent être sur une bonne voie du point de vue des buts de leur action et des moyens qu'ils utilisent. Au cours de conversations particulières que j'ai eues avec certains d'entre eux, j'ai été frappé par la qualité humaine et par l'ardeur singulièrement émouvante de ces jeunes éducateurs.” Paul Lengrand, Rapport de mission de Rome à Milan (4-13 avril 1951), UNESCO Archives Correspondence File 375 (45) A 63. Unless otherwise noted, all translations are the author's.
} 
apply to get the status of "Associated Project"; and second, to ask UNESCO to send an "Expert" or "Field Consultant" on mission to Southern Italy to study the People's Cultural Centers and to advise on the most suitable "discussion techniques" to be applied in the centers.

The inclusion of UNLA among UNESCO's Associated Projects in Fundamental Education took place without too much difficulty. However, in order to get the Expert mission to materialize, innumerable obstacles had to be overcome.

There was an initial attempt to secure, for a six-month mission, the services of Ross D. Waller, professor at the University of Manchester, who had been recommended by Lengrand as the specialist in the field most qualified for this mission. This initial attempt was documented by almost thirty exchanges from May 1951 to January 1952, taking the form of letters, telegrams, notes, and minutes, among UNESCO, UNLA, Waller, the University of Manchester, the Italian Ministry of Foreign Affairs, the Italian National Commission, the Italian Embassy in Paris, and the National Commission of the UK. (As Lengrand apologetically wrote in one of his exchanges with UNLA, asking UNLA to submit yet another official letter of request: "I am sorry to cause you this concern, but you know how important form is in this kind of business!" ${ }^{4}$ ) But all these efforts were to no avail: in spite of reiterated demands, the General Council of the University of Manchester refused to release Waller from his university duties for this mission.

Fortunately, the originally planned six-month mission by Waller was at least replaced by a one-month mission, from February 9 to March 9, by Lengrand himself, which is the mission referred to in the Courier article reproduced in this book. ${ }^{5}$ of these thirty days, Lengrand spent a total of ten days at the UNLA headquarters in Rome, first to prepare his visits to the People's Cultural Centers and then to review and evaluate his experiences. He then spent ten days visiting various centers in Calabria and Lucania, with the remaining ten days focusing on a single center, that of the village of Savoia (or "Savinia") di Lucania. He took part in the activities of the village's center and, based on this first-hand experience, identified two aims that UNESCO's expertise should help the directors of the UNLA centers to achieve:

4 "Excusez-moi de vous créer ce souci, mais vous savez combien la forme importe dans ce genre d'affaires!” Paul Lengrand to A. T. Sandesky Scelba, 11 January 1952, UNESCO Archives Correspondence File 375 (45) A 63.

5 See pp. 170-177 in this volume. 
1) ... to ensure greater cohesion and unity in defining the programs of each center;

2) ... to help members of the centers organize their experiences and lessons learned at the center in a rational and systematic way of thinking that develops judgment, reflection, and expression skills. ${ }^{6}$

Lengrand was extremely appreciative of the work carried out by UNLA teachers and, although he did not state this explicitly, he appeared to approve of UNLA's standpoint, which was very much in line with UNESCO’s:

The leaders of the League believe that it is not possible to neglect this philosophical aspect of the work they have undertaken. Indeed, they do not consider that philosophy should intervene at the end of a course of study as a crowning knowledge, but they think that the problems of intellectual method, of unity of knowledge, of link between thought and action are at the very beginning of all intellectual activity. ${ }^{7}$

These quotations are from Lengrand's official report, which he submitted at the end of his mission. But during his stay at Savoia di Lucania, Lengrand also wrote, in a much less official style, a letter addressed to his colleague John B. Bowers, Head of the Fundamental and Adult Education Division. We have chosen to reproduce this letter in full for two reasons. ${ }^{8}$ First of all, it paints a very vivid picture of the situation, to a certain extent echoing Chim's reportage. Secondly, it allows the reader to appreciate how it is possible, by drawing on archival primary sources (and in particular on UNESCO's rich archival collections), to reconstruct a multidimensional, multifaceted history based on the different versions and forms in which the same story is told.

Following Lengrand's mission, the UNESCO-UNLA exchanges intensified. Some of these exchanges dealt with the very tangible ways in which UNESCO supported UNLA: UNESCO helped UNLA acquire the equipment needed to carry out its activities, ranging from writing materials for the literacy classes and technical materials for workshops to books bought via the Gift Coupon program ${ }^{9}$ to radio sets. In

6 “1) [...] assurer une meilleure cohésion et une plus grande unité dans l'établissement des programmes de chaque centre; 2) [...] aider les membres des centres à organiser les données de leur expérience et les enseignements reçus au centre, dans un mode de pensée rationnel et systématique développant les capacités de jugement, de réflexion et d'expression." Paul Lengrand, Rapport de mission de Rome à Milan (9 février-9 mars 1952), UNESCO Archives Correspondence File 375 (45) A 6.

7 “Les dirigeants de l'Union pensent qu'il n'est pas possible de négliger cet aspect philosophique du travail qu'ils ont entrepris. En effet ils ne considèrent pas que la philosophie doive intervenir à la fin d'un cycle d'études comme couronnement du savoir, mais ils pensent que les problèmes de méthode intellectuelle, d'unité des connaissances, de liaison entre la pensée et l'action se placent au début même de toute activité intellectuelle.” Ibid.

8 Letter from Paul Lengrand to John B. Bowers, 28 February 1952, p. 158 in this volume.

9 Through its Gift Coupon program, UNESCO enabled organizations from different countries to buy books and equipment for educational activities throughout the world. Donor organizations bought 
return, UNESCO asked UNLA to send them information and communication materials on UNLA's activities. It was in response to a request of this kind by UNESCO that a UNLA representative, Anna Lorenzetto, one of the founders of UNLA, mentioned Chim's photographs in the Courier article:

We have also sent you the information material we have, as well as the photographs in our possession. Unfortunately, this material is not very abundant, because the League is poor and devotes most of its resources to its real work rather than to propaganda. But some very beautiful photos of our schools were published in the March issue of the UNESCO Courier and it will be easy for you to obtain them. ${ }^{10}$

UNLA also followed up on Lengrand's mission by requesting that UNESCO send, on a further mission to the centers, two more experts: one to work on "discussion techniques," the other to help improve the organization of the various activities in the centers, in accordance with the two needs identified in Lengrand's report cited above. When studying the letters in the UNESCO-UNLA Correspondence file, the question of whether or not UNLA's request would succeed truly reads like a suspense story, full of unexpected twists and turns.

As in the case of Lengrand's mission, this hoped-for second mission also was the subject of numerous exchanges among numerous parties, some of them preserved in the UNESCO Archives Correspondence File, while others, such as telephone conversations, personal letters, and even letters that "were never received," are only referred to, as in a letter by André Lestage, Division of Fundamental and Adult Education, dated October 22, 1954.

According to Lestage, the fact that he had never received a letter the Italian Commission claimed to have sent him earlier in the year was the reason why UNLA's request for the two experts' mission dragged on for so long that it was no longer possible to satisfy it, all funding for 1954 having run out. ${ }^{11}$

coupons and gave them to receiving organizations who could redeem them for books or equipment which were then reimbursed by UNESCO in local currency to the approved supplier.

10 "Nous vous avons également envoyé le matériel d'information dont nous disposons, ainsi que les photographies en notre possession. Malheureusement ce matériel n'est pas très abondant car l'Unione est pauvre et consacre la majeure partie de ses ressources à son travail réel plutôt qu'à la propagande. Mais Le Courrier de l'UNESCO du mois de mars a publié de très belles photos de nos écoles qu'il vous sera facile de vous procurer.” Anna Lorenzetto to Pippa Harris, 14 April 1952, UNESCO Archives Correspondence File 375 (45) A 63. Anna Lorenzetto (1914-2001) is a great figure of postwar Italy. Graduating in both philosophy and literature during the war, she was one of the founders of UNLA in 1947 and among the initiators of the People's Cultural Centers. She became President of UNLA in 1964, maintaining this position until 1981, except for a two-year interval, in 1971-72, when she served as Head of the Fundamental and Adult Education Division of UNESCO. 11 André Lestage to Lorna McPhee, 22 October 1954, UNESCO Archives Correspondence File 375 (45) A 63. 
However, on November 30, 1954, Conrad Opper, Head of the Division of Fundamental and Adult Education, wrote to H. L. Elvin, Director of the Department of Education, to tell him that there was a possibility that some funds originally earmarked for an Expert mission to Ecuador would now become available and could perhaps be allocated to the Italian mission. ${ }^{12}$

But from a note dated December 9, 1954, sent by Richard Attygalle, Program Specialist in the Division of Fundamental and Adult Education, to Conrad Opper, it emerges that the Ecuador mission was back on the agenda. Two different replies had already been drafted for Director General Luther Evans, in response to a letter sent on October 15 by M. Toscano, General Secretary of the Italian Commission, reiterating UNLA's request: a negative reply, when it was thought that the funds for 1954 had run out, and a positive reply, when the Expert mission to Ecuador seemed to have fallen through. Now that the Expert mission to Ecuador was back on the agenda, Richard Attygalle asked: What shall we do? Draft a third reply? Go back to the first negative reply? ${ }^{13}$ Opper replied laconically in a hand-written note: "Let us wait for Elvin's return. He'll be back next week. A few days more or less don't make much difference since they've already waited so long!"14

In the end, a third, negative reply was indeed drafted on December 20, $1954 .{ }^{15}$ But on the very same day - so it emerges from a letter by Lestage dated December 23, 1954 - Israel communicated to UNESCO that they would renounce the funds that had been allocated to them in response to one of their previous requests. ${ }^{16} \mathrm{~A}$ contract between UNESCO and the Italian government for a six-month UNESCO Expert mission to Italy was drafted in a great hurry and taken to the Italian Embassy to obtain the signature by the Italian government no later than December 31, 1954 the date after which the 1954 funds would no longer be available for use. In the nick of time, on December 31, 1954, the letter from the Italian Embassy arrived, confirming the signature in Rome! ${ }^{17}$

The six-month Expert mission thus being finally validated, it remained to find a suitable expert. UNESCO and in particular Lengrand once more tried to secure the services of Waller. However, once again Waller had to decline because of his univer-

12 Conrad Opper to H. L. Elvin, 30 November 1954, UNESCO Archives Correspondence File 375 (45) A 63.

13 Richard Attygalle to Conrad Opper, 9 December 1954, UNESCO Archives Correspondence File 375 (45) A 63.

14 Conrad Opper to Richard Attygalle, 9 December 1954, UNESCO Archives Correspondence File 375 (45) A 63.

15 See draft reply to Mario Toscano from Luther Evans, 20 December 1954, UNESCO Archives Correspondence File 375 (45) A 63.

16 André Lestage to M. Mahou, 23 December 1954, UNESCO Archives Correspondence File 375 (45) A 63.

17 Italian Permanent Delegation to Lorna McPhee, 31 December 1954, UNESCO Archives Correspondence File 375 (45) A 63. 
sity duties, proposing instead to accept a two-month mission in case UNESCO failed to find a suitable expert for the envisaged six-month mission. This suitable expert was eventually found, however, in the person of Joseph Rosenthal Rovan, then at the very beginning of an illustrious career as a well-known historian and politician.

By the time UNESCO proposed Rovan's mission to UNLA, it was already April 1955, so the mission was proposed to run from June 1 through December 31, 1955. However, as Anna Lorenzetto pointed out on behalf of UNLA:

From the 1st of June to the 31st of August our People's Cultural Centers are much less active, since at this time of the year most of the students are very busy working in the fields and hence physically very tired. ${ }^{18}$

So, in the end, the originally planned six-month mission was shortened once again, this time to a four-month mission, which took place from August 22 to December 22, 1955. At the end of his mission, Rovan submitted a very substantial report, resulting in a dossier of some two hundred pages. Going through it, we can measure the progress that had been made during the five years since Chim's reportage, in particular because we can draw specific comparisons with some of the people and villages of Chim's reportage that reappear in Rovan's mission report. For example, in Rovan's mission report, we meet Giuseppe Zanfini, the director of Roggiano Gravina's People's Cultural Center: “Once more, I could admire Mr. Zanfini's skills as organizer and educator," wrote Rovan. ${ }^{19}$ However, while a good deal of Chim's reportage on Roggiano Gravina features photos of adults taking their first reading and writing lessons, by the time of Rovan's mission report, the Roggiano Gravina center offered a course for future librarians targeting the very same people who just a few years earlier had learned to read and write.

And progress would continue to be made, but I shall leave the successive developments of this story to be discovered by future researchers who are invited to explore UNESCO's rich archival collections - which will be accessible online to everybody in the world, if our digitization program continues to be supported over the next few years.

18 "Du 1 juin au 31 août nos Centres de Culture Populaire développent une activité beaucoup plus réduite étant donné que le gros des élèves est à cette période de l'année engagée [sic] à fond dans les travaux des champs, et partant [sic] physiquement fort fatiguée [sic]." Anna Lorenzetto to André Lestage, 28 April 1955, UNESCO Archives Correspondence File 375 (45) A 63.

19 "Une fois de plus, j'ai pu admirer les talents d'organisateur et d'éducateur du Professeur Zanfini." Joseph Rosenthal Rovan, Rapport de mission en Italie (22 août-22 décembre 1955), UNESCO Archives Correspondence File 375 (45) A 63 (part II). 